\title{
The inclusion of internet in patient-physician relationship: a necessary reflexion
}

\author{
Suélem Barros de Lorena ${ }^{1}$
}

1. Pernambuco Healthcare College (Recife - PE)

The growth of the social importance of the internet among the media is unquestionable. Data from 2015 shows that almost half of the Brazilian population (48\%) uses the internet, being driven mainly by the use of smartphones and social media; in addition, $76 \%$ of users have daily access and with an average exposure of 5 hours/day. The benefits of this advance can be seen through the existence of countless and varied sources of search available and the consequent emergence of proactive users who, increasingly, assume the position of protagonist agents of the information acquisition process. ${ }^{1,2}$

Concomitantly with the progress of the internet, healthcare has broadened its meaning, translating as a "state of complete physical, mental and social well-being and not only the absence of affections and diseases". ${ }^{3}$ In parallel to the recognition of healthcare as one of the main concerns of contemporary men and women, there is an increase both in the availability of online information on health-related issues and in the number of users accessing the Internet for the purpose of obtaining information about their own health condition or of a relative or friend, especially if there in cases of installed illness. ${ }^{2}$

Overall, there is a presumptive view that advances in information technology interfere with medical care and is therefore "replaced by impersonal exchanges around computer screens or smartphones." This popularized view must be evaluated insofar as it is refuted by scientific evidence showing the pros and cons of the influence of the internet on doctor-patient relationships. ${ }^{2,4,5}$

In fact, it is believed that there has been, in recent years, the replacement of a passive and uninformed patient with an empowered individual willing to improve his or her own health condition. ${ }^{5}$ Modern medicine also encourages patient's participation as a of the pillars that constitute the practice of evidence-based medicine, being seen as an active individual in the decision-making process in the face of diagnostic and therapeutic possibilities offered ${ }^{6}$; the Brazilian Code of Medical Ethics defines this attitude as the principle of autonomy. ${ }^{7}$

The major advantage of online access to infor- 
mation in the doctor-patient relationship is that the patient may be more qualified to manage their own health, especially in home-based care, by engaging in partnerships with their physicians. On the other hand, doctors may feel their authority undermined by a patient with a more questioning attitude, in addition to the possible emergence of weaknesses in the trust relationship, if the guidelines given in the doctor's office differ from those found online. ${ }^{8}$

Traditionally, the physician is seen as having greater clinical knowledge when compared to the patient, thus establishing a relationship of power, in which the patient must rely on the precision of the diagnosis and on the doctor's recommendations. ${ }^{9}$ However, it is now seen that this professional can establish a collaborative model in the relationship with his/her patient, helping them to choose the method of treatment that they prefers and encouraging them to actively research in reliable and adequate sources information about their health, which positively influences the relationship. ${ }^{10}$

It is worth mentioning that physicians also enjoy the advance of the internet in accessing healthcare information, through research in databases and catalogues of academic journals. In addition to online scientific research, they can inserted themselves in social media (blogs, video sharing sites, social networks, among others), and it is possible to involve and build virtual relationships with patients and the community; in these cases, it is advised that the professional should observe his/her digital privacy, ethical aspects and attitude adopted. , $11^{11}$

Finally, it is understood that access to healthcare information online is not free from risks such as insecurity and fears, both by patients and physicians. However, the promotion of benefits through the internet, such as the creation of instruments to cope with life threatening situations and emotional relief, is already recognized as a positive effect for certain patients. ${ }^{12}$ The cognitive aspect of the patient as a determinant for the interpretation of online health information must be understood; the medical ability to critically evaluate the sources consulted is paramount in conducting the process of reflection and empowerment of people in sharing of knowl- edge. Thus, recognizing the information age as a social advance is necessary, weighing positive and negative aspects, to continue the endless process of improving communication and the doctor-patient relationship.

\section{REFERENCES}

1. Brasil. Presidência da República. Secretaria de Comunicação Social. Pesquisa brasileira de mídia 2015: hábitos de consumo de mídia pela população brasileira [Internet]. Brasília: Secom, 2014. [acesso em 2018 fev 24]. Disponível em: http://www.secom.gov.br/atuacao/pesquisa/ lista-de-pesquisas-quantitativas-e-qualitativas-de-contratos-atuais/ pesquisa-brasileira-de-midia-pbm-2015.pdf

2. Garbin HBR, Pereira Neto AF, Guilam MCR. The internet, expert patients and Medical practice: an analysis of the literature. Interface Comunicação, Saúde, Educação. [Internet]. 2008. [acesso em $2018 \mathrm{fev}$ 24]; 12(26): 579-88. Disponível em: http://socialsciences.scielo.org/scielo. php?script=sci_arttext\&pid=S1414-32832008000100011

3. Organização Mundial de Saúde. Actas oficiales de la OMS. (2):100.

4. Stevenson FA, Kerr C, Murray E, Nazareth I. Information from the Internet and the doctor-patient relationship: the patient perspective - a qualitative study. BMC Family Practice. [Internet]. 2007. [acesso em $2018 \mathrm{fev}$ 20]; 8:47. Disponível em: http://www.ncbi.nlm.nih.gov/pmc/articles/ PMC2041946/

5. Moick M, Terlutter R. Physicians' motives for professional internet use and differences in attitudes toward the internet-informed patient, physician-patient communication, and prescribing behavior. Medicine 2.0. [Internet]. 2012. [acesso em 2018 fev 03] 1(2):9. Disponível em: http://www. ncbi.nlm.nih.gov/pubmed/25075230

6. da Silva GAM. O processo de tomada de decisão na prática clínica: a medicina como estado da arte. Revista da Sociedade Brasileira de Clínica Médica. [Internet]. 2013. [acesso em 2018 fev 03] 11(1):75-9. Disponível em: http://files.bvs.br/upload/S/1679-1010/2013/v11n1/a3393.pdf

7. Conselho Federal de Medicina. Código de Ética Médica. Disponível em: http://www.portalmedico.org.br/novocodigo/integra_4.asp. [acesso em 2018 fev 28]

8. van Uden-Kraan CF, Drossaert CHC, Taal E, Smit WM, Seydel ER, van de Laar MAFJ. Experiences and attitudes of Dutch rheumatologists and oncologists with regard to their patients' health-related Internet use. Clinical Reumatology. [Internet]. 2010. [acesso em 2018 fev 20]; 29(11): 1229-36. Disponível em: http://www.ncbi.nlm.nih.gov/pubmed/20383731

9. Christmann S. The impact of online health information on the doctor-patient relationship: Findings from a qualitative study. [Monografia] [Internet]. Londres, Inglaterra: London School of Economics and Political Science; 2013. Acesso em: 20 fev. 2018. Disponível em: http://www. Ise.ac.uk/media@Ise/research/mediaWorkingPapers/MScDissertationSeries/2012/78.pdf

10. Jeongeun K, Sukwha K. Physicians' perception of the effects of Internet health information on the doctor-patient relationship. Informatics for Health and Social Care. [Internet]. 2009. [acesso em 2018 jan 30]; 34(3): 136-48. Disponível em: http://www.ncbi.nlm.nih.gov/pubmed/19670004

11. Brown J, Ryan C, Harris A. How Doctors View and Use Social Media: A National Survey. JMIR: Journal of Medical Internet Research [Internet]. 2014. [acesso em 2018 jan 27]; 16(12): 267. Disponível em: http://www. jmir.org/2014/12/e267

12. Moreland I, French T, Cumming G. The Prevalence of Online Health Information Seeking Among Patients in Scotland: A Cross-Sectional Exploratory Study. JMIR Research Protocols [Internet]. (15 de Julho,2015), [acesso em 2018 fev 15]; 4(3): e85. Disponível em: http://search.ebscohost.com/

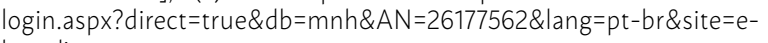
host-live. 